\title{
Effects of Exchange Rate Volatility On Non-Traditional Exports In Ghana
}

\author{
Camara Kwasi Obeng \\ Department of Economics, University of Cape Coast, Cape Coast, Ghana \\ Email: cobeng@ucc.edu.ghl/camaraobeng@yahoo.co.uk
}

\begin{abstract}
The government of Ghana has implemented a number of policies to strengthen the production and export of non-traditional products as a way of diversifying exports in Ghana with very little success. Foremost among these policies is the liberalisation of exchange rate. Meanwhile, the exchange rate has been very volatile. The study, therefore, examines the effects of exchange rate volatility on non-traditional exports in Ghana.This study employed Autoregressive Distributed Lag (ARDL) cointegration estimation technique for the investigation. The results indicate that exchange rate volatility negatively impacts Ghana's non-traditional exports. Also, the effect is greater in the longrun than it is in the short-run. Other results also show that world income, growth rate of the economy and Treasury bill rate promote non-traditional exports, but real effective exchange rate does not. rThe value of the paper lies in the discussion of the short-run and long-run effects of exchange rate volatility on non-traditional exports in the Ghanaian context.
\end{abstract}

Keywords: Exchange rate volatility, Non-Traditional Export, Autoregressive Distributed Lag, Ghana. 


\section{Introduction}

A major characteristic of the current floating exchange rate system is its volatility. Exchange rate volatility is rapid fluctuations in the value of a local currency against those of the rest of the world. Precisely, exchange rate volatility creates uncertainty in trade flows and therefore makes it difficult for exporters to plan. It has the potential to affect exports positively or negatively, depending on the degree of risk averse of the exporter (De Grauwe, 1988). Exchange rate volatility presents two main effects. These are the substitution effect and the income effect. For the substitution effect, the fear of losing export revenue when the exchange rate is very volatile will compel an exporter to produce for the domestic market instead of the world market. This will reduce exports. In the case of the income effect, the fear of losing revenue will make an exporter to export more in order to get more revenue. This will make exports increase even when the exchange rate is very volatile. Clearly, the effect of exchange rate volatility on exports is ambiguous in the theoretical literature. By extension, the impact of exchange rate volatility on non-traditional exports (NTEs), a component of exports and the focus of this study, is also unclear.

At the empirical level, the impact of exchange rate volatility on NTEsis also unsettled. While some researchers (for example, Musonda, 2008) have found a negative relationship between NTEs and exchange rate volatility, other studies (Akinlo \& Adejumo, 2014) have found a positive effect of exchange rate volatility on NTEs. The inconclusiveness of the effect of exchange rate volatility on NTEs in the empirical literature could plausibly reflect the reaction of exporters to the risk created by exchange rate volatility in trade flows, as espoused by De Grauwe (1988). That is, whether the substitution effect or the income effect dominates, it is simply a matter that in their bid to cover up for the risk created by exchange rate volatility exporters add risk premium to the cost of NTEs leading to higher prices and lower exports. Related to the above is the fact that time has implications for the magnitude of impact of exchange rate volatility on exports. Thus, exchange rate volatility is likely to create uncertainty and a significant impact on export volumes in the long-run than in the short term (Williamson, 1983 and De Grauwe, 1988, as cited in De Vita \& Abbott, 2004). Clearly, the effect of exchange rate volatility on NTEs is country specific. Notwithstanding the uncertain relationship between exchange rate volatility and NTEs, several countries, including Ghana, have adopted the floating exchange rate system to boost their NTEs.

Ghana's NTEs policy since the economic recovery programme (ERP) launched in 1983 has been to increase the value of semi-processed, processed, and manufactured export content of total exports. The transformation of the exchange rate from a fixed regime to the current floating regime as part of the economic reforms served as a major boost to NTE. In addition, a number of incentives that included import and export tax exemptions were introduced and the Ghana export promotion council (GEPC) was 
established to promote NTE. Currently, the NTEs basket of Ghana include cashew nuts, medicinal plants and parts, fresh or chilled tuna, pineapples, banana, mangoes, papaya, citrus, shea nuts, cocoa paste, articles of plastic, canned tuna, machinery and parts, veneer, hides and skins, ceramic products, traditional musical instruments, kente products and beads (ISSER, 2013). Even though the basket of NTEs has expanded over time, traditional exports, in the form of cocoa beans, minerals and timber, continue to dominate export value in Ghana.

Recent studies done by Alagidede and Ibrahim (2016), and Tarawalie, Sissoho, Conte, and Ahortor (2013) provide evidence of high exchange rate volatility (ERV)in Ghana. Alagidede and Ibrahim (2016) further provide evidence to support the claim that deviations resulting from shocks to the exchange rate market take about 15 years to be corrected in Ghana. Even though flexible exchange rate is supposed to be self-correcting, at least, theoretically, the long and slow adjustment period, in reality, could generate higher risk with deleterious effects on exports volumes (Williamson, 1983; De Grauwe, 1988 as cited in De Vita \& Abbot, 2004). What is more, the NTE sector of Ghana that is supposed to help diversify exports is dominated by small and medium scale enterprises, majority of which do not use exchange rate risk hedging facilities and also adjust prices to reflect currency fluctuations (Abor, 2005). The legitimate questions to ask at this stage are: Is the volatility of the exchange rate having any effect on NTEs? If it does, is the short-run effect different from the long-run effect? What are the other drivers of NTEs in Ghana? This study interrogated these questions.

The rest of the paper is organised as follows: Section 2 contains a review of literature. This is followed by Methodology in section 3. Results and discussion are presented in section 4 and section 5 deals with the conclusions and policy implications.

\section{Literature Review}

The section presents both theoretical and empirical literature review. The theoretical literature has focused mainly on identifying the transmission mechanism from exchange rate volatility to export volumes. One key channel identified is the risk appetite of the exporter. Thus, the reaction of exporters to exchange rate volatility depends on their disposition to risk. Exporters with low risk appetite, for instance, will reduce their exports when exchange rate volatility rises (Hooper \& Kohlhagen, 1978 and IMF, 1984 as cited in Tarawalie, et al 2013). De Grauwe (1988), extends the risk-aversion channel and argues that the exact impact on exports of exchange rate volatility rests on the latter's substitution and income effects (Tarawalie et al, 2013). Thus, an exporter who is very sensitive to risk will divert goods meant for exports to the domestic market as a coping strategy against the risk posed by exchange rate volatility. 
On the contrary, the risk-averse agent will export more if s/he sees the possibility of making more profit from the volatile exchange rate. It is evident that the theoretical literature presents two clear divergent positions on the impact of exchange rate volatility on exports. One strand of the literature supports a positive link between exchange rate volatility and exports (Franke, 1991; Sercu \& Vanhulle, 1992, as cited in Tarawalie, et al 2013). The other group, on the contrary, points to a negative effect of exchange rate volatility on exports (Cote, 1994). There is yet a third position that subscribes to no effect of exchange rate variability on exports (Serenis \& Tsounis, 2015). From the theoretical perspective, it is clear that the impact of exchange rate volatility on exports is unclear.

The empirical results are also mixed as the type of results obtained depends on the measure of volatility used in the study, the time period for the study, the estimation strategy employed, the data used for the study and the type of country. A study on exchange rate volatility and export performance in the WAMZ countries conducted by Tarawalie, Sissoho, Conte, and Ahortor (2013), employing the Dynamic OLS (DOLS) estimation technique, revealed mixed findings. In particular, the results showed a negative relationship between exchange rate volatility and exports of Liberia, Nigeria and Sierra Leone, positive relationship with exports of the Gambia, and no effect on exports of Ghana and Guinea. Tchokote, Uche and Agboola (2015) also found mixed results for some selected West African Countries (Ghana, Gambia, Togo, Cote d'Ivoire and Nigeria) in their study on the effect of exchange rate volatility and exports, using the Johansen cointegration estimation technique. Again, Serenis and Tsounis (2015) examined the effect of exchange rate volatility on sectoral exports of Germany, Sweden and the UK covering the period 1973 to 2010. The autoregressive distributed lags (ARDL) estimation technique was employed and the findings indicated that with respect to U.K. and Germany, there existed a long-run relationship between exchange rate volatility and the level of exports. However, the results showed no effects on exports in Sweden.

Other studies that have concentrated on single countries are those by Tatliyer and Yigit (2016) and De Vita and Abbott (2004). Tatliyer and Yigit (2016) investigated how exchange rate volatility influences foreign trade in Turkey. The study used quarterly time series data covering the period 1990 to 2015. The Johansen cointegration test, VECM, as well as the VAR Granger causality test were employed for the study. The findings showed that exchange rate volatility had no long-run effect on exports in Turkey. Using the ARDL bounds testing approach to cointegration, De Vita, Abbott et al. (2004) examined exchange rate volatility on U.S. exports to the rest of the world. It was found out that exchange rate volatility significantly affects the volume of exports in most cases, though the magnitude and signs varied across markets of destination. 
Yet other studies have examined the effect of structural factors on the competitiveness of exports (Agur, 2016; Anand, Perrelli, \& Zhang, 2016). Anand, Perrelli, and Zhang (2016) used a dynamic heterogeneous panel estimation technique to study the role of structural factors in reducing the responsiveness of South Africa's exports to exchange rate depreciation, using firm level export data. The results showed that electricity bottlenecks, limited product market competition and labour market constraints reduced the responsiveness of firm's exports to the rand depreciation. However, a firm's ability to diversify its exports helped it to benefit more from currency movements. In a related study, Agur (2016) used a provincial level disaggregated manufacturing export panel data set and basic panel regression as well as factor-augmented approach to control for multicollinearity among the structural variables to investigate the structural determinants of export competitiveness of Canada. The results of the study indicate that exchange rate, relative prices, real wages, labour productivity, R\&D investment, physical capital stock, inward FDI and vocational training for adults enhanced export growth.

Some studies, such as those by Akinlo and Adejumo (2014), Olufayo and Babafemi (2014), Musonda (2008) and Elbadawi (1998), focused specifically on exchange rate volatility and NTEs. In a study on the effect of exchange rate volatility on non-traditional exports in Zambia for the period 1965 to 1999, Musonda (2008) employed Generalized Autoregressive and Conditional Heteroskedasticity $(\mathrm{GARCH})$ to measure exchange rate volatility and used the Johansen cointegration technique to investigate the relationship between the two main variables. The results of the study indicated that exchange rate volatility negatively affects nontraditional exports in both the long-run and short-run. Akinlo and Adejumo (2014) examined the effect of exchange rate volatility on non-oil exports for Nigeria and found exchange rate to have a positive and significant effect on non-Oil exports. Studying the effects of exchange rate volatility on the export performance of oil and non-oil exports in Nigeria for the period 1980 to 2011, Olufayo and Babafemi (2014) employed Generalized Autoregressive Conditional Heteroscedasticity (GARCH) to estimate exchange rate volatility and applied the Seemingly Unrelated Regression (SUR) for the investigation. The results suggest that exchange rate volatility had an inverse but insignificant relationship with both the oil and nonoil exports. Elbadawe (1998) investigated the effect of exchange rate on NTE performance for a panel of 60 developing countries over 1989/90 and 1994/95. The results from random effect regression show that exchange rate volatility does not favour NTE. The results further showed that terms of trade volatility negatively affected NTE. However, human capital, proxied by schooling ratio, and imports of machines, proxied by capital goods imports or investment in capital goods, positively promoted NTE. 
There are also studies that have investigated in greater detail the effects of external resources on export supply. An example of such study is that of Njong and Tchakounte (2011). The authors investigated the spillover effect and the supply capacity effect of foreign direct investment (FDI) in Cameroon for the period 1980 - 2003. Employing the Engle-Granger two-step cointegration approach, they found that FDI inflows supported higher supply capacity and spillover effects, leading to higher export growth in Cameroon.

\section{Methodology}

This subsection deals with the theoretical model, empirical model, description of the variables and estimation strategy.

\section{Theoretical model}

The study derives its theoretical underpinning from the two-country international trade theoretical model that expresses a country's supply of exports as a function of both demand and supply factors. Savvides (1992) developed the model and it was adopted by Musonda (2008) to study the impact of exchange rate volatility on non-traditional exports in Zambia. In the model, the demand for exports is expressed as a function of real foreign income and relative foreign prices. Thus,

$$
\operatorname{Expd}_{t}=f_{1}\left(f Y_{i} f P x_{t}\right)
$$

(1)

In equation 1, the variables, $\operatorname{ExpD}, f Y$ and $f P x$ represents demand for exports of a country, level of real foreign income and relative prices of exportables abroad, respectively.

The supply of exports is modeled as a function of domestic relative prices

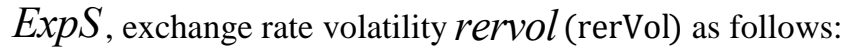

\section{Exps $_{t}=f_{2}\left(\right.$ DPx $_{i}$ rervol $\left._{t}\right)$}

\section{( 2 )}

The relative price of exportables abroad is then defined as

$$
\begin{aligned}
& \qquad P x_{t}=\frac{P x_{t}}{r e r_{t}} \\
& \text { where } r e r_{t}=\frac{E f P x_{t}}{P{ }_{t}} \text { is the exchange rate. }
\end{aligned}
$$


Replacing $f P x$ in equation 1 with $\mathrm{Px}_{1} /$ rer $_{\mathrm{t}}$ and expressing equations 1 and 2 in log form, yields:

Replacing $f P x$ in equation 1 with $\frac{P x_{1}}{r e r_{t}}$ and expressing equations 1 and 2 jn $\log$ form yields

$$
\begin{aligned}
& \exp d_{t}={ }_{o}^{+}{ }_{1} f y_{t} \quad{ }_{2} p x_{t}+{ }_{3} \text { rerer }_{t}^{+}{ }_{t}{ }^{(3)} \\
& \exp s_{t}=b_{o}+b_{1} P x_{t} \quad b_{2} p x_{t}+b_{3} \text { rervol }_{t}{ }_{t}
\end{aligned}
$$

\section{( 4 )}

and are uncorrelated error terms.

At equilibrium in the export market, expd=exps=exp and solving $\mathrm{Px}_{\mathrm{t}}$ from equation gives:

$$
P x_{t}=\frac{b_{o}}{b_{1}}+\frac{1}{b_{1}} \exp _{t} \frac{b_{2}}{b_{1}} \operatorname{rervol}_{t} \frac{b_{1}}{b_{1}}
$$

Replacing $P x$ in 3 with 5 and solving for $\exp$ results in the reduced form equation 6:

$$
\exp =\frac{a_{0} b_{1}+a_{2} b_{2}}{k}+\left(\frac{a_{1} b_{1}}{k}\right) f y_{t}+\left(\frac{a_{3} b_{1}}{k}\right) q_{t}+\left(\frac{a_{2} b_{2}}{k}\right) \text { rervol }_{t}+w
$$

withk $=a_{2}+b_{1}$ and $w=v+\left(b_{1} u\right) n$.

From equation 6, a country's exports are expressed as a linear function of foreign real income, real exchange rate and exchange rate volatility.

\section{Empirical model}

Guided by equation 6, the empirical literature and using world GDP as a proxy for foreign income, the estimable model was specified as equation 7 taking into consideration data availability: 
$\ln t e_{t}=c_{o}{ }^{+} c_{1} l W G D P_{t}{ }^{+} c_{2}$ rer $_{t}{ }^{+} c_{3}$ rervol $_{t}{ }^{+} c_{4} G D \operatorname{Pr}_{t}{ }^{+} c_{5} \operatorname{Tbill}_{t}{ }^{+} z_{t}$

where Lnte represents value of non-traditional exports for Ghana; $L$ is log operator; $l W G D P$ is world GDP, a proxy for world income. It is expected that world income will have a positive effect on lnte, because an increase (decrease) in world income will lead to a rise (fall) in the demand for non-traditional exports (Musonda, 2008; Tarawalie et al, 2013). lreris real effective exchange rate and we expect a rise (fall) of it to result in an expansion (contraction) in non-traditional exports (Musonda, 2008). rerVolis real exchange rate volatility, generated using GARCH $(1,1)$. It is the measure of the uncertainty and, hence, the risk associated with exchange rate variation and its effect on exports depends on the extent of risk aversion of exporters. GDPr is the growth rate of the economy of Ghana, a proxy for the export supply capacity of the economy, and it is expected that a rise (fall) in the growth rate will lead to increase (decrease) in non-traditional export supply ( ADB, 2005). Finally, tbill is the Treasury bill rate, a proxy for the cost of capital in Ghana. We expect a rise (fall) of the tbill rate will make capital expensive (less expensive) and, hence, lead to a fall (rise) in non-traditional exports (Rodrik (1995,1994a).

\section{Modeling Exchange rate volatility}

The variable of interest of this study is exchange rate volatility. Since exchange rate volatility is not observable, it had to be generated. Various methods have been employed to generate exchange rate volatility in the literature. These include the moving average standard deviation, autoregressive conditional heteroskedasticity (ARCH) and generalized autoregressive conditional heteroskedasticity (GARCH). There are several versions of the GARCH model but this study settled on the GARCH $(1,1)$ model, because of its parsimony and ability to capture volatility in most time series (Tarawalie et al., 2013).

The GARCH modeling process commences with mean equation (8), which expresses changes in the real effective exchange rate, $r e r$, as a function of its lagged value. The error term, et, is normally distributed with zero mean and a variance, $h_{t}$. The variance, $h_{t}$, is then used to specify the GARCH $(1,1)$ model of interest as in equation (8).

$\Delta(\operatorname{LnRER})_{t}=c_{t}+\boldsymbol{\beta} \Delta(\operatorname{LnRER})_{t-1}+e_{t}$

$e_{t} \approx N\left(0, h_{t}\right)$

$h_{t}=c_{2}+e_{t-1}^{2}+h_{t-1}$

where: $\Delta(\operatorname{LnRER})=$ difference log of the real effective exchange rate from period t to $\mathrm{t}-1$

$h=$ variance of the error term $\mathrm{e}_{\mathrm{t}}$ 
$e_{t-1}^{2}=$ the ARCH term

$h_{t-1}=$ the GARCH term

For purposes of conducting sensitivity analysis, exchange rate volatility was derived using an alternative method, the EGARCH, represented by equation 10 .

$$
\log h_{t}=w+\log h_{t 1}\left\lfloor\left|\frac{t 1}{\sqrt{h_{t 1}}}\right| \sqrt{\frac{2}{2}}\right\rfloor+\left|\frac{t 1}{\sqrt{h_{t 1}}}\right|
$$

10

The EGARCH equation stated in equation 10has the following components: $\log h_{t}$ represents the $\log$ of the conditional variance, $\frac{\varepsilon_{t-1}}{\sqrt{h_{t-1}}}$ is the standardized residual, $\alpha$ is the coefficient of the absolute values of the difference between the standardized residual and its expected value $\left(E\left(\left|\varepsilon_{t-1} / \sqrt{h_{t-1}}\right|\right)=\sqrt{2 / \pi}\right), \beta$ represents the GARCH term, $\gamma$ represents the

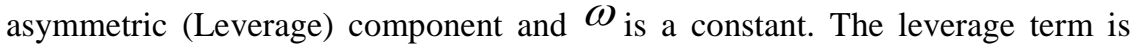
exponential, because the dependent variable is in logs. This makes the forecast of the variance positive even if the parameters are negative. The EGACH model test whether or not news drives volatility. If the leverage term is not equal to zero, if means news is an important determinant of volatility, otherwise news does not play any role in volatility.

\section{Data Sources}

The data used for the study was annual, spanning the period 1983 to 2015 . The volume of non-traditional exports was obtained from the Ghana Export Promotion Authority (GEPA). The real exchange rate volatility was generated using GARCH $(1,1)$ and EGARCH. The remaining data, that is, world GDP, real effective exchange rate, Treasury bill rate, and growth rate of Ghana were all sourced from World Bank, 2016.

\section{Estimation Strategy}

The study employed the auto regressive distributed lag (ARDL) estimation technique because of two main reasons: first, the data points used for the study is short. In particular, the data points are 32 and since ARDL has been proven to be efficient when dataset is short and there is a high probability of a different order of integration amongst variables (Pesaran et al., 2001; Pesaran \& Shin, 1999), it was employed in this study. Secondly, and more important, the ARDL was deemed to be the appropriate methodology to ensure the achievement of the 
main objective of the paper of estimating the short-run and long-run effects of exchange rate volatility on non-traditional exports in Ghana. In implementing the strategy, the study assessed the stationarity properties of the variables using the unit root tests, ADF and PP, tested for cointegration using the bounds test of Pesaran et al (2001) and then estimated the long-run and short-run equations, using OLS.

\section{Unit root test}

As a way of preparing the variables for the estimation, their Stationarity properties were verified, using the Augmented Dickey-Fuller test (ADF)(1979; 1981) and Phillips-Perron (PP) test (1988). The tests were conducted to ensure that the time series variables were stationary so as to avoid spurious regression results. Besides ensuring that the variables were stationary, the unit root test was conducted to ensure that the variables were stationary at most at first difference, that is, they are I(0) and I(1) to justify the use of the ARDL technique. The test involved an examination of the Stationarity properties of the variables in equation (7) with the null hypothesis that there is unit root against the alternative that there is no unit root.

\section{Bounds test for cointegration}

Having satisfied the criteria that the variables were a mixture of $\mathrm{I}(0)$ or $\mathrm{I}(1)$, the ARDL bounds test for cointegration (Pesaran et al., 2001) was carried out. The general form of the ARDL specification used for the test is as follows:

$$
\begin{aligned}
\Delta L N T E=\beta_{0}+ & \beta_{1} N T E_{t-1}+\beta_{2} W G D P_{t-1}+\beta_{3} L R E R+\beta_{4} R E R V O L_{t-1} \\
& +\beta_{5} L G D P r_{t-1}+\beta_{6} T B I L L_{t-1}+\sum_{i=o}^{P} \theta_{1 i} \Delta L N T E_{t-i} \\
& +\sum_{i=o}^{P} \theta_{2 i} \Delta W G D P_{t-i}+\sum_{i=o}^{P} \theta_{3 i} \Delta L R E R_{t-i} \\
& +\sum_{i=o}^{P} \theta_{4 i} \Delta R E R V O L_{t-i}+\sum_{i=o}^{P} \theta_{5 i} \Delta G D P r_{t-i} \\
& +\sum_{i=o}^{P} \theta_{6 i} \Delta T B I L L_{t-i} \\
& +\varepsilon_{t}
\end{aligned}
$$

Where $p=$ optimal lags based on the AIC, SBC and HQC criteria, $\Delta$ is the difference operator, and $\mathrm{i}=0,1,2, \ldots$, .

The study tested the long-run cointegration among the variables by estimating equation 11 using ordinary least squares (OLS). By comparing the calculated F- 
statistic with the lower critical bound, (I(0)), and the upper critical bound (I(1)) (see Pesaran et al., 2001), the specific null hypothesis that there is no long-run relationship among the variables was tested against the alternative hypothesis that there is long-run relationship among the variables.

\section{Long-run estimation}

The study obtained the long-run coefficients by determining the optimal lag length based on the Akaike's Information Criterion (AIC), Schwarz Bayesian Criterion (SBC) and Hannan-Quinn Criterion (HQC) and applying the ARDL approach.

\section{Short-run Error Correction Model}

Confirmation of long-run relationship among the variables also ensures the estimation of the short-run model, using the ARDL technique specified as follows:

$$
\begin{aligned}
\Delta L N T E_{t}=\theta_{0}+ & \sum_{i=0}^{P} \theta_{1 i} \Delta L N T E_{t-i}+\sum_{i=0}^{P} \theta_{2 i} \Delta W G D P_{t-i}+\sum_{i=0}^{P} \theta_{3 i} \Delta L R E R_{t-i} \\
& +\sum_{i=0}^{P} \theta_{4 i} \Delta R E R V O L_{t-i}+\sum_{i=0}^{P} \theta_{5 i} \Delta G D P r_{t-i} \\
& +\sum_{i=0}^{P} \theta_{6 i} \Delta T B I L L_{t-i}+\xi E C T_{t-1} \\
& +\epsilon_{t}
\end{aligned}
$$

where $\mathrm{ECT}_{\mathrm{t}-1}$ is the error correction term. The absolute size of the error term, $\mathrm{ECT}_{\mathrm{t}-1}$, determines the speed of adjustment of the model to long-run equilibrium when it is shocked. The Schwarz Bayesian Criterion (SBC) was the basis for determining the optimal lag length for the short-run estimation.

\section{Results and discussion}

This section contains descriptive statistics of the variables used in the study, results of the estimation of exchange rate volatility, unit root test, Bounds test, long-run results, short-run estimation results, diagnostic test and sensitive test.

\section{Descriptive statistics}


In this section, the descriptive statistics of the relevant variables used for the study are presented in Table 1.

Table 1: Descriptive Statistics

\begin{tabular}{lccccc}
\hline \multicolumn{7}{c}{ RER } & NTE & WGDP & GDPr & TBILL \\
\hline & & & & & \\
Mean & 141.4219 & 1068.150 & 8146.273 & 5.536269 & 24.69531 \\
Median & 104.8996 & 403.0500 & 7998.887 & 4.847879 & 22.70000 \\
Max & 545.9783 & 6784.800 & 10169.15 & 14.04600 & 47.88000 \\
Min & 69.46227 & 23.80000 & 6375.058 & 3.300000 & 9.600000 \\
Std. Dev. & 96.53471 & 1659.330 & 1180.892 & 2.227004 & 10.40749 \\
Skewness & 2.995805 & 2.170273 & 0.239975 & 2.104441 & 0.759655 \\
Kurtosis & 12.02801 & 6.917594 & 1.696591 & 7.919199 & 2.971571 \\
Jar. Bera & 158.5392 & 45.58383 & 2.572301 & 55.88427 & 3.078812 \\
Prob & 0.000000 & 0.000000 & 0.276332 & 0.000000 & 0.214508 \\
Sum & 4525.501 & 34180.80 & 260680.7 & 177.1606 & 790.2500 \\
S.S.Dev. & 288887.5 & 853546.36 & 43229663 & 153.7460 & 3357.790 \\
CV & 0.682601 & 1.553462 & 0.144961 & 0.402257 & 0.421436 \\
Obs & 32 & 32 & 32 & 32 & 32 \\
\hline Note: Max & represents & & & & \\
\end{tabular}

Note: Max represents Maximum; Min represents Minimum; Std. Dev. represents Standard Deviation; Jar. Berra represents Jarque Berra; Prob represents Probability; S. S. Dev. represents Sum of Squared Deviation; CV represents coefficient of variation while Obs also represents Observation.

Source: Computated using Eviews 9.0

It can be observed from Table 1that all the variables have positive values for mean and median. The standard deviation shows that non-traditional export (NTE) has a higher variability as confirmed by the coefficient of variation (CV) of 1.553462. In terms of Skewness, all of the variables are positively skewed. The values of the kurtosis and Skewness for real effective exchange rate (RER), NTE, GDP growth rate (GDPR) show that they are not normally distributed. This assertion is confirmed by their high Jarque-Bera statistic. Finally, the coefficient of variation shows that NTE is the most variable of all the variables.

\section{Estimation of Real Effective Exchange rate Volatility}

The estimation of real effective exchange rate volatility was done using monthly real effective exchange rate data. The obtained volatility variables were averaged to arrive at annual volatility values. The estimation results are shown in Table 2. In Table 2, all the variables of GARCH model (Model 1) are 
statistically significant at $1 \%$ level. The results further show that the sum of the $\mathrm{ARCH}$ and GARCH coefficients is very close to one, meaning that volatility shocks are persistent.

Table 2: Estimation of Real Effective Exchange rate Volatility

\begin{tabular}{lll}
\hline Variable & Model 1 & Model 2 \\
\hline$\Delta(\text { LnRER })_{t-1}$ & $\begin{array}{l}1.169302^{* * *} \\
(82.27603)\end{array}$ & -0.042528 \\
& $(-0.154744)$ \\
& & \\
RESID(-1)^2 & $0.162019^{* * *}$ & \\
& $(36.75114)$ & \\
GARCH(-1) & $0.837981^{* * *}$ & \\
& $(190.0813)$ & $-0.201463^{* * *}$ \\
C2 & & $(-4.858594)$ \\
& & $0.517902^{* * *}$ \\
C3 & & $(33.52049)$ \\
& & $0.105294^{* * *}$ \\
C4 & & $(17.13139)$ \\
& & $1.017681^{* * *}$ \\
C5 & & $(148.7531)$ \\
\hline
\end{tabular}

Figures in brackets are z-statistics.

Source: Computed using Eviews 9.0

\section{Unit Root Test}

The stationarity Status of the variables was checked to ensure that none of them was stationary at second difference. This is a requirement for the application of the ARDL estimation approach. The ADF and PP unit root tests were employed in this exercise and the results are reported in Tables 3 and 4.

Table 3: Unit Root Tests at Levels

\begin{tabular}{llllll}
\hline \multicolumn{7}{c}{$\begin{array}{l}\text { Augmented } \\
\text { Dickey-Fuller Test } \\
\text { Trend \& Intercept }\end{array}$} & Intercept & $\begin{array}{l}\text { Philips-Perron } \\
\text { Test } \\
\text { Trend \& } \\
\text { Intercept }\end{array}$ & Intercept & $\begin{array}{l}\text { Order of } \\
\text { Cointegration }\end{array}$ \\
\hline LNTE & -2.895823 & 0.338166 & -6.356222 & 0.529315 & \\
LRER & -4.17095 & -10.72891 & -13.43612 & -9.079259 & I $(0)$ \\
LWGDP & -2.088564 & -0.604868 & -2.294133 & -0.607492 & \\
Tbill & -2.156888 & -1.80436 & -2.141753 & -1.836819 & \\
GDGR & -1.403414 & -0.021497 & -1.512579 & -0.124467 & \\
RERVOLG & -3.551388 & -2.374766 & -3.547628 & -2.333722 & \\
\hline Source: Computed using Eviews & & & & &
\end{tabular}

Source: Computed using Eviews 9.0 
Table 3 reports the unit root test results at levels for all the variables. The results show that, with the exception of real effective exchange rate, all the variables are non-stationary. As a result, the first difference tests were carried out for all the variables, except real effective exchange rate and the results, as presented in Table 4, show that they are all stationary at first difference. The results of the unit root tests indicate that the variables of interest are a mixture of $\mathrm{I}(0)$ and $\mathrm{I}(1)$, thus providing enough justification for the use of the ARDL estimation technique for this study.

Table 4: Unit Root Tests at First Difference

Order of Augmented Dickey-Fuller Test Philips-Perron Test Integration

\begin{tabular}{|c|c|c|c|c|c|}
\hline Variable & Trend \& Intercept & Intercept & $\begin{array}{l}\text { Trend \& } \\
\text { Intercept }\end{array}$ & Intercept & \\
\hline LNTE & -12.26101 & -11.89711 & 11.31749 & 11.03076 & $\mathrm{I}(1)$ \\
\hline LWGDP & -4.533104 & -4.619348 & $\begin{array}{l}4.488057 \\
-\end{array}$ & -4.61275 & $\mathrm{I}(1)$ \\
\hline Tbill & -5.099724 & -5.188381 & $\begin{array}{l}5.129119 \\
-\end{array}$ & -5.22002 & \\
\hline GDPR & -4.449548 & -4.458739 & $\begin{array}{l}4.449903 \\
-\end{array}$ & -4.457145 & \\
\hline RERVOLG & -7.562547 & -7.605737 & 8.005638 & -7.703228 & \\
\hline
\end{tabular}

Source: Computated using Eviews 9.0

\section{Bounds Test}

The Bounds test was carried out to ensure that there was long-run relationship among the variables that were used in the study. The null hypothesis of the Bounds test is that there is no cointegration among the variables, while the alternative hypothesis indicates that there is cointegration among the variables. The test result for model 1 , shown in Table 5 indicates that the Bounds test statistic, 9.45, is higher than the upper bound at all levels and so the null hypothesis is rejected. That is, there is a long-run relationship or cointegration among the variables of interest. 
Table 5: ARDL Bounds Test

\begin{tabular}{rrr}
\hline \multicolumn{3}{c}{ Critical Value Bounds } \\
\hline $\begin{array}{r}\text { Significan } \\
\text { ce }\end{array}$ & $\begin{array}{r}\text { Lower } \\
\text { Bound }\end{array}$ & Upper Bound \\
& 2.08 & 3.0 \\
$10 \%$ & 2.39 & 3.38 \\
$5 \%$ & 2.70 & 3.73 \\
$2.50 \%$ & 3.06 & 4.15 \\
$1 \%$ & Value & $\mathrm{k}$ \\
\hline Test & & \\
Statistic & & \\
\hline F- & & \\
statistic & & \\
\hline Source: Computed using Eviews 9.0
\end{tabular}

Long - run estimation results for non-Traditional Exports

Having established the existence of cointegration among the variables, the longrun effects of real effective exchange rate, volatility of real effective exchange rate, world GDP, GDP growth rate for Ghana and Treasury bill rate for Ghana, on NTEs were investigated and the results are presented in Table 6.

Table 6: Long-run results for non-Traditional Exports

\begin{tabular}{lll}
\hline Variable & Model 1 & Model 2 \\
\hline LRER & 0.566436 & -6.973769 \\
& $(0.841971)$ & $(-1.52215)$ \\
RERVOLG & $-0.562050^{* *}$ & \\
& $(-3.050811)$ & \\
RERVOLE & & $-2.600290^{*}$ \\
& & $(-1.993785)$ \\
LWGDP & $5.329397 *$ & -17.323997 \\
& $(1.838169)$ & $(-0.984254)$ \\
GDPR & $0.899005 * *$ & 3.215886 \\
& $(2.510892)$ & $(1.639926)$ \\
TBILL & $0.064280^{* * *}$ & $0.088361 * *$ \\
& $(5.457074)$ & $(2.215771)$ \\
C & -67.080239 & 119.436472 \\
\hline$* * * 1 \%, * *=5 \%, *=10 \%$ &
\end{tabular}

Values in brackets are T-Statistics. 
Source: Computed using Eviews 9.0

The results from Table 6 indicate that the variable of interest, real effective rate volatility (RERVOLG, obtained from GARCH model 1) does not favour NTE and it is significant at one per cent. Specifically, a one per cent increase in real effective exchange rate volatility will cause a decrease of 0.56 per cent in nontraditional exports. The effect of exchange rate volatility on non-traditional exports is because exchange rate volatility introduces exchange rate risk. Given that non-traditional exporters are unsure of how much they will earn from exports, they will divert more of their produce to the domestic market when the exchange rate of the local currency gets volatile. This is particularly so when the exchange rate appreciates. The result obtained confirms the findings of Musonda (2008) and Elbadawi (1998), who found that real effective rate volatility negatively affected non-traditional exports. It is, however, contrary to the finding of Akinlo and Adejumo (2014), who found exchange rate volatility to have a positive and significant effect on non-Oil exports in Nigeria.

Other significant variables include the log of the GDP of the world (LGDP), a proxy for world income. The expectation was that an increase in world income should increase the demand for non-traditional exports. The result confirms the finding of De Vita and Abbott (2004). In particular, the results show that a percentage increase in world income causes the supply of non-traditional exports to increase by 5.33 per cent. The finding points to a high dependence of nontraditional exports supply in Ghana on world economic activity with a highincome elasticity (De Vita \& Abbott, 2004). The GDP growth rate of Ghana (GDPR) is also significant at the 5 per cent level of significance. This means that growth in the economy of Ghana will lead to the production and supply of more non-traditional exports. The result confirms the Flying Geese theory that posits that growth in an economy leads to the production of goods and services, including non-traditional exports and the finding of Njong and Tchakounte (2011). The Treasury bill rate (Tbill) is significant at the 1 per cent level of significant, but it carries the unexpected sign. The Treasury bill rate was used as a proxy for the cost of capital and so was meant to measure domestic constraints onthe supply of non-traditional exports. The expectation was that the sign would be negative. However, it turned out to be positive, which was contrary to expectation. The positive relationship between Treasury bill rate and NTEs is due to the fact that being the rate at which the government borrows from the public, a rise in the Treasury bill rate will entice many people to buy Treasury bill. Government then uses the resources to provide social and economic infrastructure, which have been found to boost private sector initiatives (Frimpong \& Marbuah, 2010; Asante, 2000). Finally, even though the real effective exchange rate (lrer) had the expected sign, it was not statistically significant. This finding endorses Elbadawi (1998), who found that when the 
level of the real exchange rate is combined with real exchange rate misalignment in the same model for NTE, the level of real exchange rate adds nothing further to NTE performance. Hlatshwayo and Saxegaard (2016) obtained a similar result for South Africa and attributed it to policy uncertainty.

\section{Short - run estimation results for non-Traditional Exports}

The short-run estimation shows how a deviation from short-run equilibrium in the non-traditional export supply would be corrected in the long-run. Using a mixture of lag lengths, as indicated in the title of Table 7, the estimation results are presented in Table 7.

\begin{tabular}{|c|c|c|}
\hline Variable & Model 1 & Model 2 \\
\hline$\overline{\mathrm{D}(\mathrm{LNTE}(-1))}$ & $\begin{array}{l}-0.331199 * * * \\
(-3.657787)\end{array}$ & $\begin{array}{l}0.731060^{* * *} \\
(-5673761\end{array}$ \\
\hline D(LRER) & $\begin{array}{l}0.384307 \\
(1.579811)\end{array}$ & $\begin{array}{l}2.060385 * * * \\
(3.279369)\end{array}$ \\
\hline D(LRER(-1) & & $\begin{array}{l}2.375590 * * * \\
(3.515661)\end{array}$ \\
\hline D(RERVOLG) & $\begin{array}{l}-0.142552 * * * \\
(-4.341153)\end{array}$ & \\
\hline D(RERVOLE) & & $\begin{array}{l}-0.272494 * * * \\
(-3.962689)\end{array}$ \\
\hline D(RERVOLE(-1) & & $\begin{array}{l}0.002724 \\
(0.136135)\end{array}$ \\
\hline D(LWGDP) & $8.509823^{* * *}$ & $\begin{array}{l}5.053569^{* * * *} \\
(3.302053)\end{array}$ \\
\hline D(LWGDP(-1)) & $7.035953 * * *$ & $7.960715^{* * *}$ \\
\hline & $(5.132316)$ & $(4.511667)$ \\
\hline D(GDPR) & $\begin{array}{l}0.650604 * * * \\
(4.859085)\end{array}$ & $\begin{array}{l}0.628785 * * * \\
(3.629102)\end{array}$ \\
\hline $\mathrm{D}(\operatorname{GDPR}(-1))$ & $\begin{array}{l}0.440251 * * * \\
(3.604326)\end{array}$ & \\
\hline D(TBILL) & $\begin{array}{l}0.011987 * * * \\
(4.595088)\end{array}$ & $\begin{array}{l}0.008424 * * \\
(2.866408)\end{array}$ \\
\hline D(TBILL(-1)) & $-0.006747 * *$ & \\
\hline Ecm(-1) & $\begin{array}{l}(-2.284796) \\
-0.530101 * * * \\
(-10.086414)\end{array}$ & $\begin{array}{l}-0.194311 \text { **** } \\
(-9.383500)\end{array}$ \\
\hline
\end{tabular}


Table 7: Short-run results for non-Traditional exports $(1,1,0,1,1,1)$

$* * *=1 \%, * *=5 \%, *=10 \%$

Values in brackets are T-Statistics.

Source: Computed using Eviews 9.0

Table 7shows that exchange rate volatility, world GDP, growth in the economy of Ghana, Treasury bill rate of Ghana, lag NTE and the error term have the right sign and are statistically significant. In model 1 (exchange rate volatility is obtained from GARCH), the results show that a rise in real effective exchange rate volatility contemporaneously reduces non-traditional exports. Specifically, a percentage increase in exchange rate volatility reduces non-traditional exports by 0.14 per cent. This result corroborates the result obtained for Zambia by Musonda (2008) and contradicts the finding of Tarawalie et al (2013) for Ghana. Musonda studied the effect of real effective exchange rate volatility on the performance of non-traditional exports in Zambia and found the former to negatively impact the latter. In the case of Tarawalie et al, their study was on the effect of exchange rate volatility on total export performance of the West African Monetary Zone (WAMZ) countries and they found exchange rate volatility not to influence total export performance in Ghana. The result of the current study is revealing in that it shows that even though aggregate exports for Ghana do not respond to exchange rate volatility, a component of it, nontraditional exports, does respond to exchange rate volatility.

An increase in world income by 1 per cent raises non-traditional exports contemporaneously by 8.51 per cent and also by 7.04 per cent a year after. This result is a confirmation of Keynesian theory that says that an increase in world income increases demand for exports including non-traditional exports. The result is also a confirmation of the finding of Tarawalie et al (2013). The growth rate of the economy of Ghana has positive effect on exports of non-traditional exports contemporaneously and a year after. In particular, an improvement in the economy of Ghana causes non-traditional exports to rise by 0.65 per cent in the same year and 0.44 per cent a year after. Treasury bill rate is positively signed and significant contemporaneously and becomes negative a year after. A unit increase in the Treasury bill rate raises non-traditional exports by 0.012 per cent in the immediate year, but the effect turns negative 0.007 per cent after one year. However, the net effect is still positive (0.005), which is contrary to expectation. The finding indicates that the investments government fund with resources obtained from the sale of Treasury bills complement private investment in Ghana (Frimpong \& Marbuah, 2010; Asante, 2000). Finally, the error term is negative and significant at the 1 per cent significance level. More than half of the deviation from short-run equilibrium is corrected in a year. Even though the error term obtained in this study is smaller than what Musonda (2008) obtained for Zambia, it is important to note that both error terms are 
negative and significant at the 1 per cent level of significance.

\section{Diagnostics Test Results}

To ensure that the model and estimates were devoid of any econometric problems, various diagnostic tests were conducted and the results for Model 1 are presented in Table 8.

Table 8: Diagnostic test results

\begin{tabular}{lll}
\hline Test & F-statistic & P-value \\
\hline Serial Correlation & 2.802936 & 0.1132 \\
Heteroskedasticity & 1.003521 & 0.5068 \\
Normality & 0.337715 & 0.8446 \\
Functional form & 0.443429 & 0.6669
\end{tabular}

Source: Computed using Eviews 9.0

Table 8 shows that the Breusch-Godfrey Serial Correlation LM test reveals the absence of serial correlation among the variables, as the F-statistic of 2.802936 was not statistically significant per the P-value of 0.1132. The Breusch-PaganGodfrey test for Heteroskedasticity also reported a statistically insignificant Fstatistics of 1.003521 with a P-value of 0.5058 , thus indicating the absence of heteroskedasticity among the error terms. The Ramsey-RESET stability test for the correct functional form of the model shows that the model was correctly specified, since the F-statistics of 0.443429 was insignificant, with a P-value of 0.6669. Finally, based on Jacque-Bera normality test, the study found evidence that the series in the model are normally distributed, as the F-statistics of 0.337715 was insignificant with a P-value of 0.8446 .

\section{Stability Test Results}

A further check on the stability of model 1 was carried out using the CUSUM and CUSUMQ tests. The results are shown in Figures 1 and 2. The CUSUM test, shown in Figure 1, shows that the model is stable.

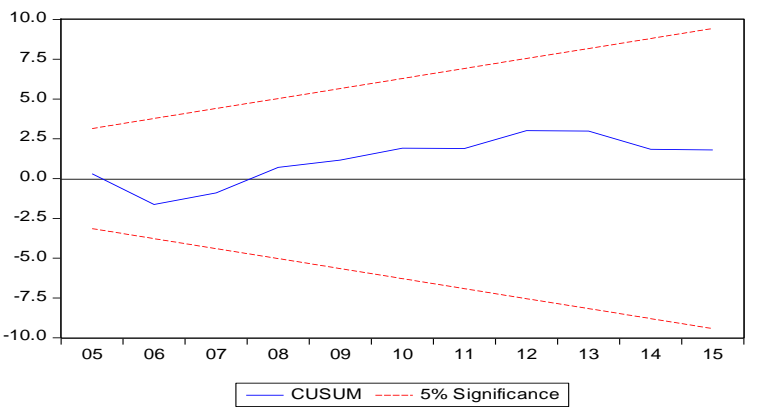




\section{Figure 1: CUSUM Test}

The CUSUMSQ test, as displayed in Figure 2, also shows that the parameters of the model are stable.

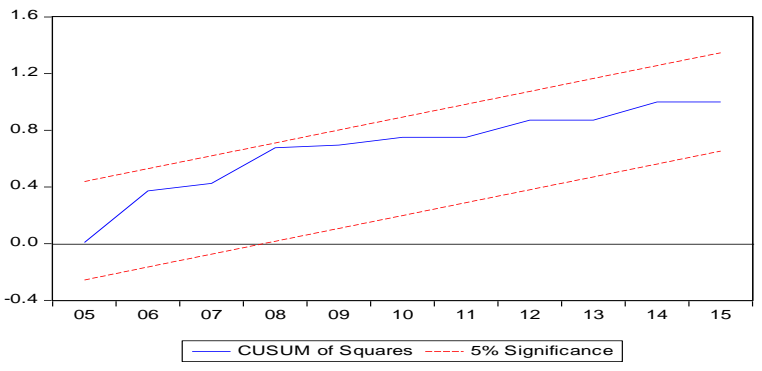

Figure 2: CUSUMSQ Test

Sensitivity Analysis

To check the robustness of the results, the short-run and long-run models were re-estimated, using exchange rate volatility generated, using the EGARCH model and the results, are shown in model 2 of Tables 6 and 7. As shown in the two Tables, exchange rate volatility (RERVOLE) is significant and negative, indicating that exchange rate volatility is an important driver of non-traditional exports in Ghana. Also, the diagnostic tests of Model 2 are shown in Tables 9, 10 and Figures 3 and 4 in the Appendix.

\section{Conclusions}

In this paper, the short-run and long-run determinants of NTEs for Ghana were investigated. The results show that exchange rate volatility, world income, growth rate of the economy, Treasury bill rate are the short-run and long-run drivers of NTEs in Ghana. Specifically, exchange rate volatility exerts a debilitating effect on non-traditional exports in both the short-run and in the long-run in Ghana. A closer look at the results reveals that the harmful effects of exchange rate volatility on non-traditional exports is severer in the long-run than in the short-run. Moreover, world income, growth rate of the economy and Treasury bill rate favour the development of NTEs in Ghana. 
The policy implications of the findings are that, first, the Bank of Ghana should step-up its exchange rate stabilization efforts to reduce the exchange rate risk imposed on exporters of non-traditional exports. Second, a conscious effort must be made by the Ghana export promotion authority to encourage exporters to use appropriate hedging facilities, such as the foreign exchange option of the Standard Chartered Bank to manage exchange rate risk. Third, commercial banks are also enjoined to develop more hedging products and educate exporters on the need to use those products to manage their foreign exchange risk. Four, there is the need for government to approach monetary and fiscal policies in a way that will ensure macroeconomic stability and also provide the needed fiscal space to undertake appropriate investments to grow the economy of Ghana. Growth rate of the economy has been shown to be a key driver of NTE in Ghana. 


\section{References}

Abor, J. (2005). Managing foreign exchange risk among Ghanaian firms, The Journal

of risk and finance, 6(4), 306 - 318.

Asante, Y. (2000). Determinants of private investment behaviour (Research Paper 100)

Nairobi, Kenya: African Economic Research Consortium Research Paper.

Asian Development Bank(ADB). (2005). Foreign direct investment spurs Asia's development, Retrieved on $18^{\text {th }}$ November, 2016 fromhttp://adb.org/

Akinlo, A. E. \& Adejumo, V. A.(2014). Exchange rate volatility and non-oil exports in

Nigeria: 1986 - 2008. International Business and Management,9(2), 70 -79 .

Alagidede, P. \& Ibrahim, M. (2016).On the causes and effects of exchange rate volatility

on economic growth: Evidence from Ghana. International Growth

Centre (IGC) Working Paper. Retrieved on $18^{\text {th }}$ November, 2016 from

www.theigc.org/wp-content/uploads/.../Alagidede-Ibrahim-2016-

Working-paper.pdf

Agur, I. (2016). Products and provinces: Disaggregated panel analysis of Canada's

DC. USA:

manufacturing exports(IMF Working Paper WP/16/193). Washington,

IMF Working Paper.

Anand, B. R., Perrelli, R., \& Zhang, B. (2016).South Africa' sexports performance: Any role for structural factors?( IMF Working Paper WP/16/24).Washington, DC. USA:IMF Working Paper.

Arize, A. C., Malindretos, I., \& Slottje, J. D. (2008).Exchange rate volatility in Latin America and its impact on foreign trade, International Review of Economics and Finance, 17, 33-44.

Cote, A. (1994). Exchange rate volatility and trade: A survey (Working Paper 94-5).

Bank of Canada.

Dickey, D. A. \& Fuller, W. A. (1981). Likelihood ratio statistics for autoregressive time

series with a unit root,Econometrica,49, $1057-1072$.

Dickey, D. A. \& Fuller, W. A. (1979). Distribution of the estimators for autoregressive 
time series with a unit root, Journal of the American Statistical Association. 74(366), $427-431$.

De Grauwe, P. (1988). Exchange rate variability and the slowdown in growth of international trade.( IMF Staff Papers35(1)).Washington, DC. USA:

IMF Staff Papers.

De Vita, G., \& Abbott, A. (2004). Real exchange rate volatility and US exports: an ARDL bounds testing approach. Economic Issues, 9(1), 69-78.

Elbadawi, I. (1998). Real exchange rate policy and non-traditional exports in developing

Countries. The United Nations World Institute for development economic research (UNU-WIDER) Resaerch for Action 46, Helsinki, Finland.

Frimpong, J. M., \& Marbuah, G. (2010). The determinants of private sector investment in

Ghana: An ARDL approach, European Journal of social sciences, $15(2), 250-261$.

Franke, G. (1991). Exchange rate volatility and international trading strategy, Journal of International Money and Finance, 10(2), 292 -307.

Hlatshwayo, S., \& Saxegaard, M. (2016). The consequences of policy uncertainty: disconnects and dilutions in the South African real effective exchange rate - export relationship (IMF Working Paper WP/16/113).Washington, DC. USA.IMF Working Paper.

Hooper, P \& Kohlhagen, S. W. (1978). The effect of exchange rate uncertainty on the prices and volume of international trade, Journal of international economics, 8, $483-511$.

Institute of Statistical, Social and Economic Research (2013).The state of the Ghanaian economy in 2012. ISSER, Legon, Accra.

Musonda, A. (2008). Exchange rate volatility and non-traditional exports

Performance in Zambia, 1965-1999(Research Paper 185):,Nairobi, Kenya: African Economic Research Consortium.

Njong, A., M \& Tchakounte, R. (2011). Investigating the effects of foreign direct

investment on export growth in Cameroon, International Journal of current research, 3(5), 184-191.

Olufayo, M. B. \& Babafemi, F. A. (2014). Exchange rate volatility and sectoral export of Nigeria: Case of Oil and Non-Oil Sectors, Journal of Economics and Sustainable Development,5(10), 66-75.

Pesaran, M. H., Shin, Y. \& Smith, R., J. (2001). Bounds testing approaches to 
Analysisof level relationships,Journal of Applied Econometrics, 16, $289-326$.

Pesaran, M. H.,\& Shin, Y. (1999). An autoregressive distributed lag modelling approach to cointegration analysis.In Strom, S (ed), Econometrics and Economic theory in the $20^{\text {th }}$ Century: the Ragnar Frisch Centennial Symposium, Cambridge University Press, New York. Phillips, P. C. B., \& Perron, P. (1988). Testing for a unit root in time series regression.

Biometrika, 75(2), 335 -346.

Rodrik, D. (1995). Trade strategy, export and investment: Another look at East Asia,

Institute of policy reforms.(Discussion paper). Washington DC.

Rodrik, D. (1994a). Getting interventions right: How South Korea and Taiwan grew rich.

(Working Paper series, No. 4964).NBER.

Savvides, A. (1992). Unanticipated exchange rate variability and growth of international

trade. WeltwirtschaftlichesArchiv, Bd. 128, $446-468$.

Serenis, D. \& Tsounis, N. ( 2015). The effects of exchange rate volatility on sectoral

Journal of

exports: evidence from Sweden, UK, and Germany,International

Economics and Econometrics, 5(1), 71 - 107.

Tarawalie, A, B., Sissoho, M., Conte, M., \& Ahortor, C., R. (2013).Export performance

and exchange rate volatility: Evidence from the WAMZ.(Occasional paper series, 1(5). West African Monetary Institute (WAMI)

Tatliyer, M., \& Yigit, F. (2016). Does Exchange Rate Volatility Really Influence Foreign Trade? Evidence from Turkey.International Journal of Economics and Finance, 8(2), 33.

Tchokote, J., Uche, M. E., \& Agboola, Y. H. (2015). Impact of exchange rate volatility on net-export in selected West African countries. AshEse Journal of Economics, 1(4), 57-73.

World Bank (2016).World development indicators 2016.Retrieved on $10^{\text {th }}$ September, 2016 from data.worldbank.org/data-catalog/worlddevelopment-indicators. 


\section{Appendice}

Table 9: ARDL Bounds Test

for Model 2

\begin{tabular}{|c|c|c|c|}
\hline 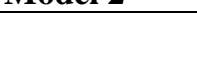 & & \multicolumn{2}{|c|}{ Critical Value Bounds } \\
\hline Significance & Lower Bound & & Upper Bound \\
\hline $10 \%$ & 2.08 & & 3.0 \\
\hline $5 \%$ & 2.39 & & 3.38 \\
\hline $2.50 \%$ & 2.70 & & 3.73 \\
\hline $1 \%$ & 3.06 & & 4.15 \\
\hline Test Statistic & Value & $\mathrm{k}$ & \\
\hline
\end{tabular}

Source: Author's own computation

Table 10: Diagnostic test results for Model 2

\begin{tabular}{lll}
\hline Test & F-statistic & P-value \\
\hline Serial Correlation & 2.479396 & 0.13235 \\
Heteroskedasticity & 0.846087 & 0.6251 \\
Normality & 1.589802 & 0.451626 \\
Functional form & 0.529913 & 0.4819 \\
\hline
\end{tabular}

Stability Test Results For Model 2

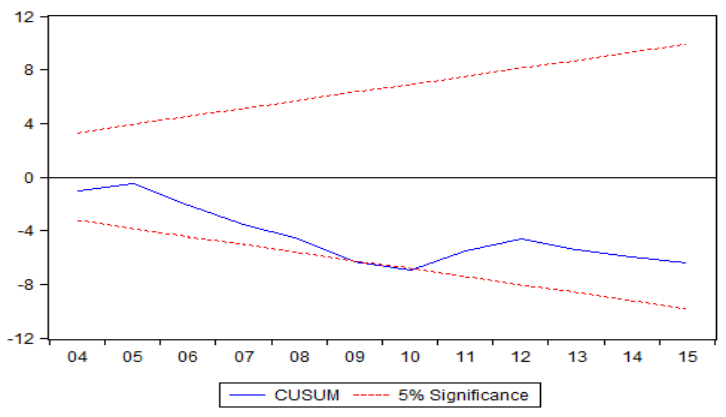

Figure 3: CUSUM Test 


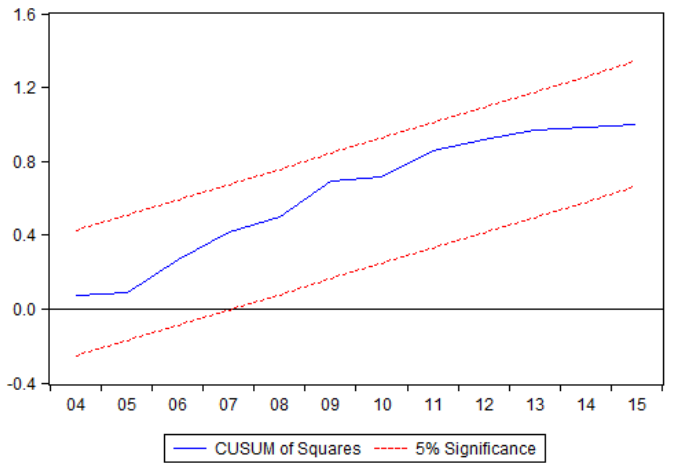

Figure 4: CUSUMSQ Test 